\title{
The Relationship Between the Organizational Change Cynicism and Organizational Commitment of Teachers
}

\author{
Mehmet Akif Helvaci ${ }^{1}$, Ali Kiliçoğlu ${ }^{2}$ \\ ${ }^{1}$ Assoc. Prof. Dr., Uşak University, Educational Management, Educational Sciences Department, Turkey \\ ${ }^{2}$ MSc Student., Uşak University, Educational Management, Educational Sciences Department, Turkey \\ Correspondence: Ali Kiliçoğlu, MSc Student., Uşak University, Educational Management, Educational Sciences \\ Department, Turkey.
}

Received: October 19, 2018

doi:10.11114/jets.v6i11a.3806
Accepted: October 24, $2018 \quad$ Online Published: November 29, 2018

URL: https://doi.org/10.11114/jets.v6i11a.3806

\begin{abstract}
Organizational change cynicism is the situation that includes negative attitudes of the employees towards the changes in the organizations. Organizational commitment means the involvement of the employees into the organizations by being identified within the organizations. The aim of this study is to determine the organizational change cynicism levels and organizational commitment levels of teachers and to find out the correlation between the organizational change cynicism levels and organizational commitment levels of teacher. 352 primary and elementary school teachers working in Denizli took part in this study. According to the research results, the organizational change cynicism level of teachers is low, the organizational commitment level is high and the correlation between organizational change cynicism and organizational commitment is high. This study is a part of master thesis with the title "Öğretmenlerde Örgütsel Değişim Sinizmi ve Örgütsel Bağlllık Düzeyleri Arasındaki İlişki” which was supported by Research Fund (2018/TP003) of Uşak University.
\end{abstract}

Keywords: organizational change cynicism, organizational commitment, teachers

\section{Introduction}

Everything in life undergoes change. The era in which we are living involves the economic, social, cultural, political, societal and technological changes (Erdoğan, 2015). Organizations are also in a state of change. That's why, organizations make an effort to serve, find solutions to the problems and adapt to the changes. Appropriate methods and strategies should be embraced to make the change process successful. Moreover, leaders and managers should have efficient knowledge and information in managing the change (Helvac1, 2015).

Organizational change is a non-linear phenomenon that does not have any explicit beginning and endless process. Therefore, the change process can be perceived as eternal and confusing. Effective changes clamp the many developmental efforts together. A success can trigger the other success. In the organizations, the change can become in the ascending order and descending order. Hence, everyone in the organizations should act in a body. Organizational change has a personal dimension as well. The beliefs and values of the employees in the organizations are crucial in terms of the successful change process (Moran and Brightman, 2000).

When the organizational change is unsuccessful, organizational change cynicism can be seen among the employees. Organizational change cynicism means that the employees lose the belief in the successful change. Therefore, the employees can resist against the change process (Reichers et al., 1997). Unsuccessful change can affect the organizational commitment levels of the employees. Organizational commitment can become more of an issue among the employees and organizations. As a result of organizational commitment, the employees can show high performance in the organizations (Mowday, 1998).

According to Rus (2013), every organization should renew and change so as to remain standing. Organizations can be exposed to different types of changes. They can be in line with interior and exterior plans. Each organization may not be successful in every change process. Therefore, organizations need a perfect change plan. At the same time, the managers should be well-prepared in the change management.

Cynicism is a type of skepticism by which suspicion opposes the reality and the causes. Cynicism is a powerful 
negative situation (Adorno et al., 1950; Turner and Valentine, 2001). According to Maslach and Reichter (2016), cynicism is a situation which has hostile and separatist reaction. This situation develops as a response to excessive emotional exhaust. At the same time, cynicism can appear when the employees are not behaved rightfully.

\section{Organizational Cynicism}

Organizational cynicism is an attitude which shows up in terms of beliefs, emotions and behaviors. That's why, organizational cynicism can appear because of many reasons. Organizational cynicism is an important motive that affects the organizations and the employees (James, 2005). Organizational change cynicism involves reactions to the past unsuccessful changes and makes the change leaders lose their faith. Many employees may show resistance to the change process which results in organizational change cynicism. This situation can be described as a belief that there isn't any integrity in the organization (Reichers et al., 1997; Grama and Todericiu, 2016; Bommer et al., 2005).

The organizational change cynicism, seen among the employees, is an unwanted result that decreases the effect of change efforts. Human resources units have crucial impacts on the change cynicism among the employees. When the employees have low cynicism, they behave understandingly towards the human resources units. Otherwise, the employees can show unfavorable behaviors against the human resources units. When the human resources units have strategic change agent roles, the change cynicism levels of the employees may be decreased. In addition, the human resources units should have efficiencies to make successful changes (Brown et al., 2017).

\section{Organizational Commitment}

Organizational commitment is described as the affiliation of the individuals' emotions with the organization. Organizational commitment is also known as the presence of the involvement of the employees in the organizations (Kanter, 1968; Buchanan, 1974; Porter et al., 1974). According to O'Reilly and Chatman (1986), organizational commitment is a physiological interest felt by the individuals in the organizations. According to Güney (2007), organizational commitment is the feelings and attitudes shown toward the organizations. Organizational commitment is a more general phenomenon than job satisfaction because organizational commitment is devoted to both organizations and job.

According to O'Reilly and Chatman (1986), there are three dimensions of organizational commitment: compliance commitment, identification commitment and internalization commitment. Compliance commitment is a type of commitment that is based on rewards. The employees who have compliance commitment stay away from punishment. Identification commitment means the degree by which the employees are proud of their organizations. Internalization commitment means the harmony between the individuals' values and beliefs.

The employees who have high organizational commitment will have high performance, motivation and job satisfaction. That's why, organizational commitment is very important in terms of the functionality of the organizations. Also, organizational commitment is in a negative correlation with job leaving and low performance (Ersoy and Bayraktaroğlu, 2012).

Just as all organizations, educational organizations can be affected by the change process. That the educational organizations are influenced by the changes have an impact on organizational change management and organizational commitment. Unsuccessful change management in the educational organizations can reveal resist against the change, change cynicism and low organizational commitment. With successful change management, the employees will not show any resist against the change process. As a result, low change cynicism and high organizational commitment can be seen among the employees. In this way, both the employees in the educational organizations and the students will be successful.

To evaluate the organizational cynicsm in Turkish schools, the following research questions were examined:

1) What is the organizational change cynicism level of teachers?

2) What is the organizational commitment level of teachers?

3) What is the correlation between organizational change cynicism and organizational commitment?

\section{Method}

With using survey method in this study, it is aimed to determine the relation between the levels of organizational change cynicism and organizational commitment of teachers working in the schools in Denizli province of Turkey. The population of this research involves the primary and elementary school teachers. The research sample is 352 teachers in total. The demographic variables of the research are presented in Table 1.

Two research data collection tools were used in the study. The first one is "Organizational Change Cynicism Scale" which was developed by Helvacı and Çavdar (2017). The second scale is "Organizational Commitment Scale" which was developed by Balay (2000). 
"Organizational Change Cynicism Scale" consists of 17 items. The scale has three dimensions: cognitive dimensioin has six items, affective dimension has five items and behavioral dimension has six items. The scale is a 5-point likert-type scale. Each item is graded with " $1=$ Not at all", " $2=$ To a slight degree", " $3=$ To a moderate degree", " $4=$ To a great degree" and " $5=$ Totally agree".

"Organizational Commitment Scale" consists of 27 items. The scale has three dimensions: compliance dimension has eight items, identification dimension has eight items and internalization dimension has eleven items. The scale is a 5-point likert-type scale. Each item is graded with " $1=$ Not at all", "2=To a slight degree", " $3=$ To a moderate degree", "4=To a great degree" and "5=Totally agree". The eight items of the scale (1., 2., 3., 4., 5., 6., 7. and 8. items) were coded reversely.

Table 1. Demographic Variables of Teachers $(n=352)$

\begin{tabular}{|c|c|c|c|}
\hline Variables & & $\mathrm{f}$ & $\%$ \\
\hline \multirow[t]{3}{*}{ Gender } & Female & 142 & 40.3 \\
\hline & Male & 210 & 59.7 \\
\hline & Total & 352 & 100 \\
\hline \multirow[t]{3}{*}{ Area } & Classroom Teacher & 131 & 37.2 \\
\hline & Branch Teacher & 221 & 62.8 \\
\hline & Total & 352 & 100 \\
\hline \multirow[t]{6}{*}{ Seniority } & $1-5$ Years & 72 & 20.5 \\
\hline & 6-10 Years & 109 & 31 \\
\hline & 11-15 Years & 52 & 14.8 \\
\hline & 16-20 Years & 55 & 15.6 \\
\hline & 21 Years and Over & 64 & 18.2 \\
\hline & Total & 352 & 100 \\
\hline \multirow[t]{5}{*}{ Educational Background } & Associate's Degree & 16 & 4.5 \\
\hline & Bachelor's Degree & 296 & 84.1 \\
\hline & Master's Degree & 38 & 10.8 \\
\hline & Doctor's Degree & 2 & 0.6 \\
\hline & Total & 352 & 100 \\
\hline \multirow{6}{*}{$\begin{array}{l}\text { Working Duration } \\
\text { in the school }\end{array}$} & $1-5$ Years & 263 & 74.7 \\
\hline & 6-10 Years & 56 & 15.9 \\
\hline & 11-15 Years & 20 & 5.7 \\
\hline & 16-20 Years & 11 & 3.1 \\
\hline & 21 Years and Over & 2 & 0.6 \\
\hline & Total & 352 & 100 \\
\hline
\end{tabular}

According to table 1 , there are 142 females (40.3\%) and 210 males (59.7\%); 131 classroom teachers $(37.2 \%)$ and 221 branch teachers $(62.8 \%)$; $72(20.5 \%)$ 1-5 years seniority teachers, $109(31 \%)$ 6-10years seniority teachers, $52(14.8 \%)$ 11-15 years seniority teachers, $55(15.6 \%)$ 16-20 years seniority teachers and $64(18.2 \%) 21$ years and over seniority teachers; 16 (4.5\%) associate's degree teachers, $296(84.1 \%)$ bachelor's degree teachers, $38(10.8 \%)$ master's degree teachers and $2(0.6 \%)$ doctor's degree teachers. Also, there are263 (74.7\%) 1-5 years working duration teachers, 56 (15.9\%) 6-10 years working duration teachers, 20 (5.7\%) 11-15 years working duration teachers, $11(3.1 \%)$ 16-20 years working duration teachers and $2(0.6 \%) 21$ years and over working duration teachers in the research.

KMO value of the "Organizational Change Cynicism Scale" is 0.893 and Barlett sphericity result is significant $(\mathrm{x} 2=2283.270, \mathrm{p}<.01)$. Five items were removed from the scale and the reliability result of the scale was calculated as 0.89. KMO vallue of the "Orghanizational Commitment Scale" is 0.939 and Barlett sphericity result is significant $(\mathrm{x} 2=5726.789, \mathrm{p}<.01)$. Two items were removed from the scale and the reliability result of the scale was calculated as 0.94 .

In order to analyze the data, SPSS v18.0 software was used. Descriptive analysis was performed to show the percentage, frequency and the mean results. Pearson correlation analysis was used to determine the relation between the organizational change cynicism and organizational commitment levels of teachers. 


\section{Findings}

The levels of teachers' organizational change cynicism are presented in Table 2.

Table 2. The Levels of Teachers' Organizational Change Cynicism ( $\mathrm{n}=352)$

\begin{tabular}{lcccc}
\hline $\begin{array}{l}\text { Organizational Change Cynicism } \\
\text { Dimensions }\end{array}$ & and & & & \\
\hline Cognitive Dimension & 2,23 & 1,09 & Low \\
Affective Dimension & 3,39 & 1,17 & Moderate \\
Behavioral Dimension & 1,61 &, 771 & Very Low \\
Total Organizational Change Cynicism & 2,16 &, 798 & Low \\
\hline
\end{tabular}

According to Table 2, the cognitive level of the teachers is low $(\overline{\mathrm{x}}=2.23)$, the affective level of the teachers is moderate $(\overline{\mathrm{x}}=3.39)$ and the behvioral dimension of the teachers is very low $(\overline{\mathrm{x}}=1.61)$. The level of the total organizational change cynicism is low $(\overline{\mathrm{x}}=2.16)$. The levels of teachers' organizational commitment are presented in Table 3.

Table 3. The Levels of Teachers' Organizational Commitment $(n=352)$

\begin{tabular}{lccc}
\hline Organizational Commitment & and & & \\
Dimensions & $\overline{\mathrm{x}}$ & $\mathrm{Sd}$ & Level \\
\hline Compliance Dimension & 4,29 &, 79 & Very High \\
Identification Dimension & 3,30 &, 89 & Moderate \\
Internalization Dimension & 3,71 &, 87 & High \\
Total Organizational Commitment & 3,78 &, 72 & High \\
\hline
\end{tabular}

According to Table 3 , the compliance level of teachers is very high $(\bar{x}=4.29)$, the identification level of teachers is moderate $(\bar{x}=3.30)$ and the internalization level of the teachers is high $(\bar{x}=3.71)$. The level of the total organizational commitment is high $(\overline{\mathrm{x}}=3.78)$. The relation between the organizational change cynicism and organizational commitment levels of the teachers is presented in Table 4.

Table 4. The Pearson Correlation Results of the Organizational Change Cynicism and Organizational Commitment Levels of Teachers $(\mathrm{n}=352)$

\begin{tabular}{|c|c|c|c|c|c|c|c|c|}
\hline Değişkenler & 1 & 2 & 3 & 4 & 5 & 6 & 7 & 8 \\
\hline 1. Bilişsel Boyut & 1 & .519 & $.544^{* *}$ & $-.354^{* *}$ & $-.242^{* *}$ & $-219^{* *}$ & $.916^{* *}$ & $-316^{* *}$ \\
\hline 2. Duyuşsal Boyut & & 1 & $.298^{* *}$ & $-.235^{* *}$ & $-.106^{*}$ & $-.098^{*}$ & $.660^{* *}$ & $-.167^{* *}$ \\
\hline 3. Davranışsal Boyut & & & 1 & $-.576^{* *}$ & $-.212^{* *}$ & $-.315^{* *}$ & $.786^{* *}$ & $-.431^{* *}$ \\
\hline 4. Uyum Boyutu & & & & 1 & $.431^{* *}$ & $.558^{* * *}$ & $-.491^{* * *}$ & $.776^{* *}$ \\
\hline 5. Özdeşleşme Boyutu & & & & & 1 & $.650^{* * *}$ & $-.249^{* * *}$ & $.816^{* *}$ \\
\hline 6. İçselleştirme Boyutu & & & & & & 1 & $-.275^{* * *}$ & $.909^{* *}$ \\
\hline 7. Toplam Örgütsel Değișim Sinizmi Düzeyleri & & & & & & & 1 & $-.394^{* *}$ \\
\hline 8. Toplam Örgütsel Bağll1ık Düzeyleri & & & & & & & & 1 \\
\hline
\end{tabular}

According to Table 4, the relation between the organizational change cynicism and organizational commitment levels of teachers is low, negative and significant $(\mathrm{r}=-0.394, \mathrm{p}<.01)$.

There are positive and significant relations among the dimensions of organizational change cynicism levels. The relation between the cognitive leveland affective level is moderate, positive and significant $(r=0.519, \mathrm{p}<.01)$. The relation between the cognitive level and behvioral level is moderate, positive and significant $(r=0.544, p<.01)$. The relation between affective level and behavioral level is low, positive and significant $(r=0.298, p<.01)$.

There are positive and significant relations among the dimensions of organizational commitment. The relation between the comliance level and identification level is moderate, positive and significant $(\mathrm{r}=0.431, \mathrm{p}<.01)$. The relation between 
compliance level and internalization level is moderate, positive and significant $(\mathrm{r}=0.558, \mathrm{p}<.01)$. The relation between identification level and internalization level is moderate, positive and significant $(r=0.650, p<.01)$.

\section{Results, Conclusions and Recommendations}

The organizational change cynicism level among the primary and elementary school teachers working in Denizli have low organizational change cynicism. Just as this study, Kahveci and Demirtaş (2015) found out the organizational cynicism of teachers at low level. Helvacı and Çetin (2012) reveled in their study that the organizational cynicism levels among 311 teachers working in Uşak are low. However, according to Polat and Güngör (2014), the level of organizational change cynicism among 715 teachers is moderate and job satisfaction is high.

The organizational commitment level among the primary and elementary school teachers working in Denizli have high organizational commitment. Kushman (1992) found out that the organizational commitment among the teachers is high and this situation helps the teachers and students become successful. Zan (2016) revealed that the organizational commitment is high among the 63 teachers. According to Rainayee and Khan (2012), the organizational commitment is high among 200 teachers and makes them successful.

In this study, it has been found out that the relation between the organizational change cynicism and organizational commitment is negative. According to Wanous et al. (2000), there is a negative correlation between the organizational change cynicism and organizational commitment. Barton and Ambrosini (2013) revealed that organizational change cynicism decreases the organizational commitment and this brings about low performance among the employees. Abraham (2000) found out in his study that organizational change cynicism causes low job satisfaction and alienation. This situation affects the organizational commitment adversely.

Teachers should be included in the change process and the aims of the change should be relayed to the employees clearly. The changes should be carried out in line with the needs. Teachers and school principals should be trained to manage the changes successfully. Both male and female teachers should have equal responsibilities and rights in the school environments. School principals should support the teachers during the change process and help them become motivated. Also, school principals should be in social and cultural activities together with the teachers.

\section{References}

Abraham, R. (2000). Organizational cynicism: bases and consequences. Genetic, Social, And General Psychology Monographs, 126(3), 269-292.

Balay, R. (2000). Yönetici ve Öğretmenlerde Örgütsel Bağlllık. Ankara: Nobel Yayıncılık.

Barton, L. C., \& Ambrosini, V. (2013). The moderating effect of organizational change cynicism on middle manager strategy commitment. The International Journal of Human Resource Management, 24(4), 721-746. https://doi.org/10.1080/09585192.2012.697481

Bommer, W. S., Rich, G. A., \& Rubin, R. S. (2005). Changing Attitudes about Change: Longitudinal Effects of Transformational Leader Behavior on Employee Cynicism about Organizational Change. Journal of Organizational Behavior, 26(7), 733-753. https://doi.org/10.1002/job.342

Brown, M., Kulik, C. T., Cregan, C., \& Metz, I. (2017). Understanding the Change-Cynicism Cycle: The Role of HR. Human Resource Management, 56(1), 5-24. https://doi.org/10.1002/hrm.21708

Buchanan, B. (1974). Building organizational commitment: The socialization of managers in work organizations. Administrative science quarterly, 533-546.

Erdoğan, İ. (2015). Eğitimde Değişim Yönetimi (4. bs). Ankara: Pegem Akademi.

Ersoy, S., \& Bayraktaroğlu, S. (2012). Örgütsel Bağlllık. Içinde D. Ergun Özler (Ed.), Örgütsel Davranışta Güncel Konular (2. bs). Bursa: Ekin Basım Yayın Dă̆ıtım.

Grama, B., \& Todericiu, R. (2016). Change, Resistance to Change and Organizational Cynicism. Studies in Business \& Economics, 11(3), 47-54. https://doi.org/10.1515/sbe-2016-0034

Güney, S. (2007). Örgütsel Bağl1lık. Içinde Salih Güney (Ed.), Yönetim ve Organizasyon (2. bs). Ankara: Nobel Yayın Dă̆ıtım.

Helvacı, M. A. (2015). Eğitim örgütlerinde değişim yönetimi: İlke, yöntem ve süreçler (3. bs). Nobel Yayın Dağıtım.

Helvacı, M. A., \& Çavdar, E. (2017). Change cynicism scale: development, validity and reliability. European Journal of Education Studies.

Helvacı, M. A., \& Çetin, A. (2012). İlköğretim Okullarında Görev Yapan Öğretmenlerin Örgütsel Sinizm Düzeylerinin Belirlenmesi (Uşak İli Örneği). Journal of Turkish Studies, 7(3), 1475-1497. 
https://doi.org/10.7827/TurkishStudies.3454

James, M. S. L. (2005). Antecedents and Consequences of Cynicism in Organizations: An Examination of the Potential Positive and Negative Effects on School Systems. (Yayımlanmamış Doktora Tezi). ABD: Florida State University.

Kahveci, G., \& Demirtaş, Z. (2015). Ilkokul, ortaokul ve lise öğretmenlerinin örgütsel sinisizm algilarinin incelenmesi. Elektronik Sosyal Bilimler Dergisi, 14(52). https://doi.org/10.17755/esosder.01813

Kanter, R. M. (1968). Commitment and social organization: A study of commitment mechanisms in utopian communities. American sociological review, 499-517. https://doi.org/10.2307/2092438

Kushman, J. W. (1992). The organizational dynamics of teacher workplace commitment: A study of urban elementary and middle schools. Educational administration quarterly, 28(1), 5-42. https://doi.org/10.1177/0013161X92028001002

Maslach, C., \& Leiter, M. P. (2016). Chapter 43 - Burnout. Içinde G. Fink (Ed.), Stress: Concepts, Cognition, Emotion, and Behavior (ss. 351-357). San Diego: Academic Press. Geliş tarihi gönderen http://www.sciencedirect.com/science/article/pii/B9780128009512000443

Moran, J. W., \& Brightman, B. K. (2000). Leading organizational change. Journal of Workplace Learning, 12(2), 66-74. https://doi.org/10.1108/13665620010316226

Mowday, R. T., Porter, L. W., \& Steers, R. M. (2013). Employee-organization linkages: The psychology of commitment, absenteeism, and turnover. Academic press.

O'Reilly, C. A., \& Chatman, J. (1986). Organizational commitment and psychological attachment: The effects of compliance, identification, and internalization on prosocial behavior. Journal of applied psychology, 7l(3), 492. https://doi.org/10.1037/0021-9010.71.3.492

Polat, S., \& Gungor, G. (2014). Relationship between organizational change cynicism and some variables in Turkish public schools. The Anthropologist, 18(3), 1019-1027. https://doi.org/10.1080/09720073.2014.11891585

Porter, L. W., Mowday, R. T., \& Dubin, R. (1974). Unit performance, situational factors, and employee attitudes in spatially separated work units. Organizational behavior and human performance, 12(2), 231-248. https://doi.org/10.1016/0030-5073(74)90048-8

Porter, L. W., Mowday, R. T., \& Dubin, R. (1974). Unit performance, situational factors, and employee attitudes in spatially separated work units. Organizational behavior and human performance, 12(2), 231-248. https://doi.org/10.1016/0030-5073(74)90048-8

Rainayee, R. A., \& Khan, S. Z. (2012). Organisational Commitment: An Empirical Study of Govt. and Private School Teachers. Acta Universitatis Danubius. Economica, 8(6).

Reichers, A. E., Wanous, J. P., \& Austin, J. T. (1997). Understanding and Managing Cynicism about Organizational Change. The Academy of Management Executive (1993-2005), 11(1), 48-59. https://doi.org/10.5465/ame.1997.9707100659

Rus, D. E. (2013). Organizational change management and its implementations in a public institution (Yayımlanmamış Yüksek Lisans Tezi). Avusturya: University of Vienna.

Wanous, J. P., Reichers, A. E., \& Austin, J. T. (2000). Cynicism about Organizational Change: Measurement, Antecedents, and Correlates. Group \& Organization Management, 25(2), 132-153. https://doi.org/10.1177/1059601100252003

Zan, S. Y. (2016). Hemşirelerin alglladıkları örgütsel desteğin örgütsel sinizm ve örgütsel bağlllklariüzerine etkisi (Yayımlanmamış Yüksek Lisans Tezi). Erzurum: Atatürk Üniversitesi, Sağlık Bilimleri Enstitüsü.

\section{Copyrights}

Copyright for this article is retained by the author(s), with first publication rights granted to the journal.

This is an open-access article distributed under the terms and conditions of the Creative Commons Attribution license which permits unrestricted use, distribution, and reproduction in any medium, provided the original work is properly cited. 